\title{
Two Unrecorded Species of the Snapper (Perciformes: Lutjanidae) Collected from Jeju Island, Korea
}

\author{
Maeng Jin Kim ${ }^{1}$, Byung Yeob Kim², Joon Sang Kim ${ }^{3}$ and Choon Bok Song ${ }^{2 *}$ \\ ${ }^{1}$ Fisheries Resources Management Division, National Fisheries Research and Development Institute, Busan 618-756, Korea \\ ${ }^{2}$ College of Ocean Sciences, Jeju National University, Jeju 690-756, Korea \\ ${ }^{3}$ Korea Fisheries Resources Agency Jeju Branch, Jeju 695-929, Korea
}

\begin{abstract}
Two unrecorded species of the snapper, Lutjanus malabaricus (296.0 mm standard length [SL]) and L. stellatus (350.0 mm SL) belonging to the family Lutjanidae, were first collected from the western coastal waters of Jeju Island, Korea. L. malabaricus is characterized by having a dark marking on the upper half of the caudal peduncle, a band of vomerine teeth that does not protrude posteriorly at the middle, and nine anal soft rays. Compared to its Korean relative, L. malabaricus is distinguishable by having rows of scales that run obliquely in the dorsal-posterior direction above the lateral line (vs. parallel to the lateral line in $L$. argentimaculatus). L. stellatus can be identified by the absence of wavy blue lines on the head (vs. many blue lines in L. rivulatus) and presence of a white spot above the lateral line (vs. a black blotch on the lateral line in L. rivulatus). We propose new Korean names, "Jin-hong-tung-dom" and "Huin-jeom-tung-dom," for L. malabaricus and L. stellatus, respectively.
\end{abstract}

Key words: Lutjanidae, First record, Jeju Island, Korea

\section{Introduction}

There are approximately 185 species of the snapper (family Lutjanidae) in 17 genera worldwide (Nelson, 2006); 11 species in five genera have been reported in Korea to date (Kim et al., 2005, 2007, 2011). Snappers are commercially important food fishes and generally occur in tropical and subtropical seas. These fishes are described as having enlarged canine teeth on jaws, small teeth, and scales on the cheek, preopercle and gill cover, but no scales on the snout or the preorbital area (Nelson, 2006). Within the family Lutjanidae, the genus Lutjanus comprises 64 species worldwide including seven species from the coastal waters of Korea, and it is morphologically distinguished from other genera by having a steeply sloped upper profile and a nearly flattened lower profile, a large mouth, well-developed teeth with fang-like canines at the front of the jaws, and vomerine teeth (Allen, 1985; Lee, 1987). Recently, L. malabaricus and L. stellatus were collected from the western coastal waters of Jeju Island, Korea. Here we described the morphological characteristics of these two species and have added them to the list of Korean fish fauna.

\section{Materials and Methods}

The specimens were preserved in $10 \%$ formalin for a week and then transferred to $70 \%$ ethanol. Counts and measurements followed the methods of Hubbs and Lagler (1964). The examined specimens were deposited at the Fish Genetics and Breeding Laboratory, Jeju National University (JNU), Korea.
Open Access http://dx.doi.org/10.5657/FAS.2012.0313

This is an Open Access article distributed under the terms of the Creative Commons Attribution Non-Commercial License (http://creativecommons. org/licenses/by-nc/3.0/) which permits unrestricted non-commercial use, distribution, and reproduction in any medium, provided the original work is properly cited. pISSN: 2234-1749 eISSN: 2234-1757
Received 9 October 2012; Revised 14 November 2012 Accepted 29 November 2012

*Corresponding Author

E-mail: cbsong@jejunu.ac.kr 


\section{Results and Discussion}

\section{Lutjanus malabaricus (Schneider, 1801) (Table 1, Fig. 1) \\ (new Korean name: Jin-hong-tung-dom)}

Sparus malabaricus Bloch and Schneider, 1801: 278 (Coromandel coastal, India).

Lutjanus malabaricus: Krishnan and Mishra, 1983: 226 (India); Dor, 1984: 141 (Red sea); Allen and Swainston, 1988: 80 (north-western Australia); Randall, 1995: 201 (Oman); Myers, 1999: 146 (Micronesian); Randall and Lim, 2000: 628 (South China sea); Shimada, 2002; 823 (Japan); Allen and Adrim, 2003: 39 (Indonesia).

\section{Material examined}

JNU-91, $296.0 \mathrm{~mm}$ in standard length (SL), Hallim-eup, Jeju-si, Jeju Island, Korea, gill net, caught at a depth of approximately $25 \mathrm{~m}$, December 2, 2010.

\section{Description}

Counts for the present specimen are shown in Table 1. Measurements are presented as percentages against SL: body width 14.4 ; body depth 36.2 ; head length 39.7 ; predorsal fin length 39.1; prepectoral fin length 35.8; preventral fin length 39.5; preanal fin length 70.3; dorsal fin base length 48.9; pectoral fin base length 5.7; ventral fin base length 4.5 ; anal fin base length 12.4; upper jaw length 12.5 ; interorbital length 8.9; eye diameter 6.4; snout length 13.9; caudal fin peduncle depth 15.0; caudal fin peduncle length 10.7.

Body oblong, compressed, covered with ctenoid scales aligned in oblique rows above the lateral line and horizontal rows below the lateral line, except for a few oblique rows anteriorly. Scales present on the base of the soft dorsal and anal fins; three and five series of scales on the cheek and opercle, respectively. Eye somewhat oval; snout projecting and rounded; mouth large and oblique; posterior margin of the upper jaw does not reach below the eye; interorbital area well convex; vomerine teeth in a crescentic patch; posterior margin of preopercle serrate without preopercular notch; interopercle bony knob absent; dorsal fin continuous and posterior profile of its soft part rounded; pectoral fin pointed and its posterior tip reaching below the eighth dorsal spine; posterior profile of anal soft fin rounded; caudal fin truncate.

\section{Color when fresh}

Head and body nearly uniformly reddish; all fins except pectoral fin reddish with black posterior margins; pectoral fin reddish-yellow; dorsal part of caudal peduncle with black marking (Fig. 2).

\section{Distribution}

Known from Indo-West Pacific: Persian Gulf to Fiji, north to Taiwan, south to New South Wales (Myers, 1991) and Ko- rea (Jeju Island, present study).

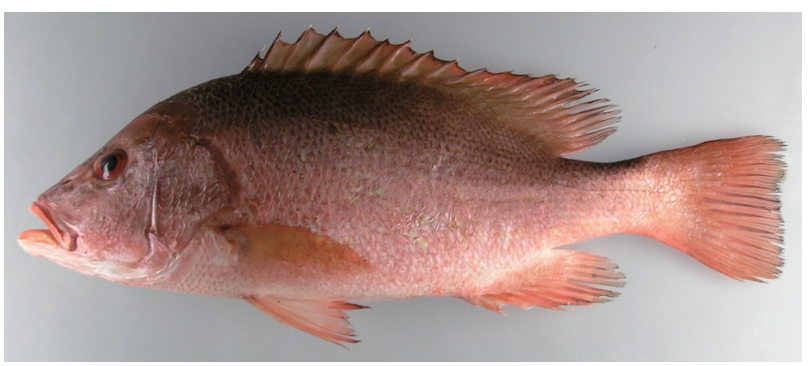

Fig. 1. Lutjanus malabaricus (Schneider), JNU-119, 296.0 mm standard length, Jeju Island, Korea.

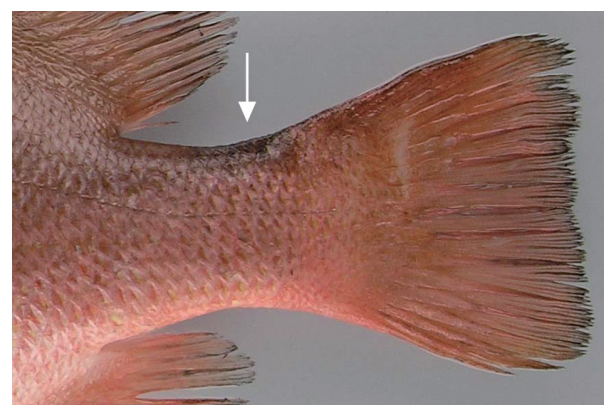

Fig. 2. A black marking indicating with an arrow on the caudal peduncle.

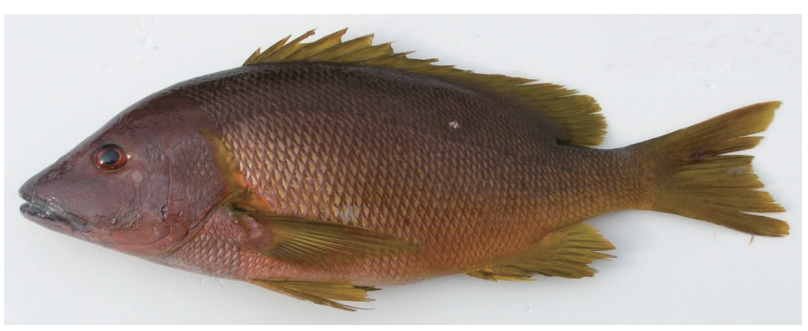

Fig. 3. Lutjanus stellatus Akazaki, JNU-91, $350.0 \mathrm{~mm}$ standard length, Jeju Island, Korea

Table 1. Comparison of morphological characters of Lutjanus malabaricus

\begin{tabular}{lccc}
\hline $\begin{array}{l}\text { Morphological } \\
\text { characters }\end{array}$ & $\begin{array}{c}\text { Present } \\
\text { study }\end{array}$ & $\begin{array}{c}\text { Allen and Talbot } \\
(\mathbf{1 9 8 5})\end{array}$ & $\begin{array}{c}\text { Lee } \\
\mathbf{( 1 9 8 7 )}\end{array}$ \\
\hline Standard length (mm) & 296 & $115-495$ & 325,330 \\
$(n=1)$ & $(n=21)$ & $(n=2)$ \\
Counts & XI, 13 & XI, 12-14 & XI, 13 \\
Dorsal fin rays & 16 & $16-17$ & 17 \\
Pectoral fin rays & I, 5 & - & I, 5 \\
Pelvic fin rays & III, 9 & III, 8-9 & III, 8-9 \\
Anal fin rays & $4+12$ & $4-7+12-14$ & $4-5+12-13$ \\
Gill rakers & 47 & $46-50$ & $45-46$ \\
Lateral lines & & & \\
\hline
\end{tabular}




\section{Remarks}

The present specimen was collected from Jeju Island, Korea, and was characterized by having a black marking on the upper half of the caudal peduncle and rows of scales running obliquely above the lateral line, a band of vomerine teeth that does not protrude posteriorly at the middle, and nine anal soft rays. Thus, the morphological characteristics agreed well with previous reports of L. malabaricus (Table 1) (Lee, 1987; Shimada, 2002). Lutjanus malabaricus is morphologically very similar to L. timorensis, which inhabits the coastal waters of Japan, but differs from the latter by having nine anal soft rays (vs. eight anal soft rays in L. timorensis) and lacking a black blotch on axilla (vs. a black blotch in L. timorensis) (Shimada, 2002). In Korea, this species is distinguished from a similar species, L. argentimaculatus by having rows of scales that run obliquely in the dorsal-posterior direction above the lateral line (vs. parallel to the lateral line in L. argentimaculatus). Because the body of L. malabaricus is reddish overall, we propose a new Korean name, "Jin-hong-tung-dom," for this species.

\section{Lutjanus stellatus Akazaki, 1983 (Table 2, Fig. 3)}

(new Korean name: Huin-jeom-tung-dom)

Lutjanus stellatus Akazaki, 1983: 367 (Miyazaki, Japan); Lee, 1987: 290 (Taiwan); Sadovy and Cornish, 2000: 123 (Hong Kong); Randall and Lim, 2000: 618 (South China sea); Shimada, 2002: 824 (Japan).

\section{Material examined}

JNU-119, 350.0 mm in SL, Daejeong-eup, Jeju Island, Korea, gill net, December 18, 2010.

\section{Description}

Counts for the present specimen are shown in Table 2 . Measurements are presented as percentages against SL: body width 15.9; body depth 41.4; head length 36.7 ; predorsal fin length 35.1 ; prepectoral fin length 35.1 ; preventral fin length

Table 2. Comparison of morphological characters of Lutjanus stellatus

\begin{tabular}{lccc}
\hline $\begin{array}{l}\text { Morphological } \\
\text { characters }\end{array}$ & $\begin{array}{c}\text { Present } \\
\text { study }\end{array}$ & $\begin{array}{c}\text { Akajaki } \\
(\mathbf{1 9 8 3})\end{array}$ & $\begin{array}{c}\text { Lee } \\
\mathbf{( 1 9 8 7 )}\end{array}$ \\
\hline Standard length $(\mathrm{mm})$ & $\begin{array}{c}350.0 \\
(n=1)\end{array}$ & $\begin{array}{c}304.5 \\
(n=1, \text { holotype })\end{array}$ & $\begin{array}{c}325-330 \\
(n=2)\end{array}$ \\
Counts & $\mathrm{X}, 14$ & $\mathrm{X}, 14$ & $\mathrm{X}, 14$ \\
Dorsal fin rays & 18 & 18 & 17 \\
Pectoral fin rays & $\mathrm{I}, 5$ & $\mathrm{I}, 5$ & \\
Pelvic fin rays & $\mathrm{III}, 8$ & $\mathrm{III}, 8$ & $\mathrm{III}, 8$ \\
Anal fin rays & $5+13$ & $5+12$ & $6+10$ \\
Gill rakers & 48 & 49 & 47 \\
Lateral lines & & & \\
\hline
\end{tabular}

38.3; preanal fin length 69.7 ; dorsal fin base length 51.7 ; pectoral fin base length 7.1 ; ventral fin base length 3.7 ; anal fin base length 15.6; upper jaw length 15.4; interorbital length 10.9; eye diameter 6.0; snout length 13.1; caudal fin peduncle depth 12.1; caudal fin peduncle length 12.9.

Body elongate, oval and compressed, covered with ctenoid scales aligned in oblique rows above the lateral line and horizontal rows below the lateral line. Scales present on the base of the dorsal and anal fins; three and five series of scales on the cheek and opercle, respectively. Eye moderate in size relative to the head; snout projecting; mouth large and oblique; posterior margin of the upper jaw nearly reaching below the middle of the eye; interorbital area well convex; one series of 13 weak conical teeth on the lateral outer side of the lower jaw and a short patch of villiform teeth on the lateral inner side on both jaws; four and three canines on the anterior part of the upper and lower jaw, respectively; a band of vomerine teeth without a posterior extension; posterior margin of preopercle finely serrate with a shallow preopecular notch; dorsal fin continuous and posterior profile of its soft part rounded; pectoral fin pointed and its posterior tip not reaching below the first spine of the anal fin; posterior profile of the anal soft fin rounded; caudal fin slightly forked.

\section{Color when fresh}

Body brown and tinged yellowish-orange or pale orange; head uniformly brownish; all fins and posterior margin of opercle yellowish brown; a white spot on the side above the lateral line.

\section{Distribution}

Japan (Shimada, 2002), Taiwan (Lee, 1987), South China sea (Randall and Lim, 2000) and Korea (Jeju Island, present).

\section{Remarks}

The present specimen was characterized by having a white spot on the upper half of the body and a band of vomerine teeth that did not protrude posteriorly at the middle (Lee, 1987; Shimada, 2002). Those and the remaining morphological characters of the specimen agreed well with previous reports of L. stellatus (Table 2). Lutjanus stellatus resembles L. rivulatus, which inhabits the coastal waters of Korea, but differs from the latter by lacking wavy blue lines on its head (vs. many blue lines in L. rivulatus) and by having a white spot above the lateral line (vs. a black blotch on the lateral line in L. rivulatus) (Lee, 1987; Shimada, 2002;). We propose a new Korean name, "Huin-jeom-tung-dom," for this species.

\section{Acknowledgments}

This work was funded by a grand from the National Fisheries Research \& Development Institute, Korea (RP-2012FR-059). 


\section{References}

Akazaki M. 1983. A new lutjanid fish, Lutjanus stellatus, from Southern Japan and a related species, L. rivulatus (Cuvier). Jpn J Ichthyol 29, 365-373.

Allen GR. 1985. FAO Species Catalogue. Vol. 6. Snappers of the World. An Annotated and Illustrated Catalogue of Lutjanid Species Known to Date. FAO Fisheries Synopsis No. 125. FAO, Rome, IT, pp. 1-128.

Allen GR and Adrim M. 2003. Coral reef fishes of Indonesia. Zool Stud 42, 1-72.

Allen GR and Swainston R. 1988. The Marine Fishes of North-western Australia. A Field Guide for Anglers and Divers. Western Australian Museum, Geraldton, AU.

Allen GR and Talbot FH. 1985. Review of the snappers of the genus $\mathrm{Lu}$ tjanus (Pisces: Lutjanidae) from Indo-pacific, with the description of a new species. Indo-pac Fishes 11, 1-87.

Bloch ME and Schneider JG. 1801. M.E. Blochii, Systema Ichthyologiae Iconibus cx Ilustratum. Post obitum auctoris opus inchoatum absolvit, correxit, interpolavit Jo. Gottlob Schneider, Saxo. Berolini. Sumtibus Auctoris Impressum et Bibliopolio Sanderiano Commissum, Berolini, IT.

Dor M. 1984. Checklist of the Fishes of the Red Sea. (CLOFRES). Israel Academy of Sciences and Humanities, Jerusalem, IL.

Hubbs CL and Lagler KF. 1964. Fishes of the great lake region. Bull Granbrook Inst Sci 26, 1-213.

Kim BJ, Nakaya K and Endo H. 2007. Three juvenile snappers of the genus Lutjanus (Perciformes: Lutjanidae) collected from Jeju Island, Korea. J Fish Sci Technol 10, 68-73.
Kim IS, Choi Y, Lee CL, Lee YJ, Kim BJ and Kim JH. 2005. Illustrated Book of Korean Fish. Kyo-Hak Publishing Co. Ltd., Seoul, KR, pp. 320-322.

Kim JS, Kim BY and Song CB. 2011. First record of the green jobfish, Aprion virenscens (Perciformes: Lutjanidae) from Korea. Korean J Ichthyol 23, 310-313.

Krishnan S and Mishra SS. 1983. On a collection of fish from KakinadaGopalpur sector of the east coast of India. Rec Zool Surv India 93, 201-240.

Lee SC. 1987. Fishes of the family Lutjanidae of Taiwan. Bull Inst Zool Acad Sin Taipei 26, 279-303.

Myers RF. 1991. Micronesian Reef Fishes: A Practical Guide to the Identification of the Coral Reef Fishes of the Tropical Central and Western Pacific. Coral Graphics, Guam, US

Myers RF. 1999. Micronesian Reef Fishes: A Comprehensive Guide to the Coral Reef Fishes of Micronesia. 3rd rev. ed. Coral Graphics, Guam, US.

Nelson JS. 2006. Fishes of the World. 4th ed. John Wiley and Sons Inc., Hoboken, NJ, US.

Randall JE 1995. Coastal Fishes of Oman. Crowford House Publishing Pty Ltd., Bathurst, AU.

Randall JE and Lim KKP. 2000. A checklist of the fishes of the South China Sea. Raffles Bull Zool Suppl 8, 569-667.

Sadovy Y and Cornish AS. 2000. Reef Fishes of Hong Kong. Hong Kong University Press, Hong Kong, CN.

Shimada K. 2002. Lutjanidae. In: Fishes of Japan with Pictorial Keys to the Species. Nakabo T, ed. Tokai University Press, Tokyo, JP, pp. 819-832. 